\title{
STRATEGI PENGENDALIAN KECEMASAN DALAM PENGAJARAN KETERAMPILAN BERBICARA BAHASA INGGRIS
}

(Second Language Anxiety Strategy and Controlling Nervousness in Teaching Speaking to EFL Students)

\author{
Feby Meuthia Yusuf
}

Faculty of Letters of Ekasakti University

\begin{abstract}
Anxiety does not always necessarily affect language learners negatively, but excessive levels of anxiety can have a negative effect on learning and teaching process. It can inhibit their ability to learn effectively. Consequently, it causes emotional stress and lower self-esteem and self confidence. This lack of confidence is damaging because it can prevent the learners from using their current ability and discovering their full potential. Second language anxiety can be reduced by improving language proficiency and making reasonable, achievable language learning goals for them to alleviate language anxiety and make the most of their language ability.
\end{abstract}

Keywords: Second language anxiety, controlling nervousness

\section{Pendahuluan}

Dalam belajar suatu bahasa banyak faktor yang menentukan apakah pelajaran bahasa tersebut dapat dikuasai atau tidak. Faktor-faktor yang dapat menentukan apakah pelajaran bahasa Inggris tersebut dapat dikuasai oleh para siswa antara lain adalah faktor guru, 
ruang kelas, motivasi, tingkat kecemasan yang dimiliki oleh siswa, strategi belajar yang diterapkan oleh para siswa dan faktor lainnya. Rasa cemas yang dimiliki oleh siswa merupakan salah satu faktor yang memberi kontribusi yang cukup besar dalam menentukan apakah pelajaran bahasa Inggris dapat diterima atau tidak. Tingkat kecemasan berbahasa yang dimiliki oleh seseorang sangat menentukan proses belajar. Kecemasan dalam proses belajar telah menjadi suatu permasalah yang selama ini menjadi perhatian. Tingkat kecemasan yang dimiliki oleh seorang siswa ketika sedang belajar berperan besar dalam menentukan apakah proses belajar dapat berjalan atau tidak terhadap proses belajar bahasa asing.

\section{Pembahasan}

Kecemasan merupakan salah satu bentuk emosi individu yang berkenaan dengan adanya rasa terancam atau tertekan oleh sesuatu. Perasaan cemas dapat dialami siapa saja, baik anak-anak, remaja, dan orang tua. Perasaan cemas dapat muncul pada saat kita menghadapi sesuatu yang kita anggap penting, memasuki situasi yang baru dan cemas terhadap tanggapan mengenai hasil tindakan kita. Menurut Atkinson (1991): "Kecemasan adalah emosi yang tidak menyenangkan yang ditandai istilah kekhawatiran, keprihatinan, dan rasa takut-yang kadang-kadang kita dalam tingkat yang berbeda-beda." Kartono (1999) membagi kecemasan menjadi dua yaitu : 1) Kecemasan yang wajar. Artinya kecemasan yang dialami seseorang dalam tingkat yang wajar, sifatnya tidak terlalu berat dan tidak terlalu ringan. Hal ini dapat berguna untuk perkembangan kepribadiannya. 2) Kecemasan yang terlalu berat dan berakar secara mendalam dalam diri seseorang. Bila seseorang mengalami kecemasan ini, biasanya ia tidak mampu mengatasi. Menurut beberapa pendapat di atas, dapat disimpulkan bahwa kecemasan ada beberapa macam, yaitu kecemasan nyata, kecemasan neurotik, kecemasan moral, kecemasan sebagai suatu sifat, kecemasan sebagai suatu keadaan, kecemasan umum dan kecemasan fobia. Sedangkan kecemasan komunikasi interpersonal termasuk kecemasan umum karena sering muncul di kehidupan sehari-hari.

Perasaan cemas juga sering muncul di lingkungan sekolah. Perasaan tersebut menyebabkan siswa merasa tidak nyaman dan tidak tenang. Kecemasan yang dialami siswa secara wajar dapat dianggap memiliki nilai positif sebagai motivasi, tetapi 
apabila sudah tidak wajar dan berlebihan, bisa mengganggu aktivitas yang seharusnya dilakukan di lingkungan sekolah. Pada umumnya kecemasan yang muncul di lingkungan sekolah antara lain, kecemasan dalam menyampaikan pendapat dan pertanyaan di kelas, kecemasan saat diskusi, kecemasan saat berkomunikasi dengan guru, kecemasan saat menghadapi ujian, dan lain-lain. Kecemasan dengan intensitas yang wajar dapat dianggap memiliki nilai positif sebagai motivasi, tetapi apabila intensitasnya sangat kuat dan bersifat negatif justru malah akan menimbulkan kerugian dan dapat mengganggu terhadap keadaan fisik dan psikis individu yang bersangkutan.

Dalam psikoanalisis, kecemasan dipandang sebagai komponen utama dan memegang peranan penting dalam dinamika kepribadian seorang individu. kecemasan dapat dibagi ke dalam tiga tipe:

1. Kecemasan realistik yaitu rasa takut terhadap ancaman atau bahayabahaya nyata yang ada di dunia luar atau lingkungannya.

2. Kecemasan neurotik adalah rasa takut ketika insting (Id) akan lepas dari kendali dan menyebabkan dia berbuat sesuatu yang bisa membuatnya dihukum. Kecemasan neurotik bukanlah ketakutan terhadap insting-insting itu sendiri, melainkan ketakutan terhadap hukuman yang akan menimpanya jika suatu insting dilepaskan. Kecemasan neurotik berkembang berdasarkan pengalaman yang diperolehnya pada masa kanak-kanak atau situasi yang membuatnya tertekan dalam situsi tertentu, seperti dalam kelas belajar, terkait dengan hukuman dan ancaman dari guru maupun teman-temannya, jika dia melakukan perbuatan impulsif.

3. Kecemasan moral yaitu rasa takut terhadap suara hati (super ego). Orangorang yang memiliki super ego yang baik cenderung merasa bersalah atau malu jika mereka berbuat atau berfikir sesuatu yang bertentangan dengan moral. Sama halnya dengan kecemasan neurotik, kecemasan moral juga berkembang berdasarkan pengalaman yang diperolehnya.

Selanjutnya, dikemukakan pula bahwa kecemasan yang tidak dapat ditanggulangi dengan tindakan-tindakan yang efektif disebut traumatik, yang akan 
menjadikan seseorang merasa tak berdaya, dan selalu ketakutan. Apabila ego tidak dapat menanggulangi kecemasan dengan cara-cara rasional, maka ia akan kembali pada cara-cara yang tidak realistik yang dikenal istilah mekanisme pertahanan diri (self defense mechanism), seperti: represi, proyeksi, pembentukan reaksi, fiksasi dan regresi. Semua bentuk mekanisme pertahanan diri tersebut memiliki ciri-ciri umum yaitu: mereka menyangkal, memalsukan atau mendistorsikan kenyataan dan mereka bekerja atau berbuat secara tak sadar sehingga tidak tahu apa yang sedang terjadi.

Dalam berkomunikasi diperlukan suatu proses timbal balik yang aktif antara dua individu atau lebih dalam memberi dan menerima informasi sehingga terjadinya saling pengertian. Anwar (2008), menjelaskan hambatan komunikasi sebagai bentuk reaksi negatif dari individu berupa kecemasan yang dialami seseorang ketika berkomunikasi, baik komunikasi antar pribadi, komunikasi umum atau komunikasi massa. Individu yang mengalami hambatan komunikasi (communication apprehension) akan merasa cemas bila berpartisipasi dalam komunikasi bentuk yang lebih luas, tidak sekedar cemas berbicara di muka umum. Individu tidak mampu untuk mengantisipasi perasaan negatifnya, dan sedapat mungkin berusaha untuk menghindari berkomunikasi. Jadi, istilah hambatan komunikasi (communication apprehension) mencakup kondisi yang lebih luas, baik kecemasan komunikasi antar pribadi, komunikasi kelompok, dan komunikasi massa.

Menurut Spielberger (1996), Individu yang mengalami kecemasan dalam berbagai bentuk, termasuk cemas ketika berkomunikasi antar pribadi sebenarnya berada dalam kondisi emosi yang sama sekali tidak menyenangkan. Lazarus (1996) menjelaskan lebih lanjut bahwa perasaan cemas sebenarnya merupakan pengalaman yang samar-samar disertai dengan adanya perasaan tidak berdaya. Sifat kecemasan dikatakan subjekif, artinya bahwa kejadian yang menjadi penyebab dan reaksi yang dialami tiap individu berbeda. Pada umumnya tanda-tanda yang menyertai kecemasan pada tiap orang adalah sama, yaitu ditandai dengan perubahan psikologis seperti perasaan tegang, takut, khawatir, perubahan fisiologis seperti denyut jantung, pernafasan, dan tekanan darah yang meningkat. Lazarus (1996) mengemukakan tentang beberapa ciri kecemasan komunikasi antar pribadi, yaitu: 
1. Unwilingnes atau ketidaksediaan untuk berkomunikasi yang ditandai oleh kecemasan, intoversi, rendahnya frekuensi partisipasi dalam berbagai situasi komunikasi.

2. Avoiding atau penghindaran dari partisipasi karena pengalaman komunikasi yang tidak menyenangkan, dengan indikasi: kecemasan, kurangnya pengenalan situasi komunikasi yang mempengaruhi intimasi dan empati.

3. Control atau rendahnya pengendalian terhadap situasi komunikasi, yang terjadi karena: faktor lingkungan, ketidakmampuan menyesuaikan diri dengan individu yang berbeda, reaksi lawan bicara.

Kecemasan dapat dialami siapapun dan di mana pun, termasuk juga oleh para siswa di sekolah. Kecemasan yang dialami siswa di sekolah bisa berbentuk kecemasan realistik, neurotik atau kecemasan moral. Karena kecemasan merupakan proses psikis yang sifatnya tidak tampak ke permukaan maka untuk menentukan apakah seseorang siwa mengalami kecemasan atau tidak, diperlukan penelaahan yang seksama, dengan berusaha mengenali simptom atau gejalagejalanya, beserta faktor-faktor yang melatarbelangi dan mempengaruhinya. Kendati demikian, perlu dicatat bahwa gejala-gejala kecemasan yang bisa diamati di permukaan hanyalah sebagian kecil saja dari masalah yang sesungguhnya, ibarat gunung es di lautan, yang apabila diselami lebih dalam mungkin akan ditemukan persoalan-persoalan yang jauh lebih kompleks.

Di sekolah, banyak faktor-faktor pemicu timbulnya kecemasan pada diri siswa. Target kurikulum yang terlalu tinggi, iklim pembelajaran yang tidak kondusif, pemberian tugas yang sangat padat, serta sistem penilaian ketat dan kurang adil dapat menjadi faktor penyebab timbulnya kecemasan yang bersumber dari faktor kurikulum. Begitu juga, sikap dan perlakuan guru yang kurang bersahabat, killer dan kurang kompeten merupakan sumber penyebab timbulnya kecemasan pada diri siswa yang bersumber dari faktor guru. Penerapan disiplin sekolah yang ketat dan lebih mengedepankan hukuman, iklim sekolah yang kurang nyaman, serta sarana dan pra sarana belajar yang sangat terbatas juga 
merupakan faktor-faktor pemicu terbentuknya kecemasan pada siswa.yang bersumber dari faktor manajemen sekolah.

Language anxiety merupakan rasa cemas yang timbul ketika seseorang belajar bahasa Inggris. Kecemasan merupakan faktor utama yang bisa menghambat proses belajar. Kecemasan itu sendiri merupakan perasaan subjektif terhadap ketegangan (tension), state of apprehension, nervousness dan worry yang diasosiasikan dengan terangsangnya system syaraf autonom yang sisebabkan oleh ketakutan yang tidak jelas yang secara tidak langsung berhubungan dengan object.

Menurut Wolman dan Sricker (1994), Foreign Language Anxiety (kecemasan belajar bahasa asing), merupakan kekhawatiran atau reaksi emosi negatif yang timbul ketika belajar atau menggunakan bahasa Inggris. Pengertian dari Foreign Language Anxiety adalah "distinct complex of self perceptions, beliefs, feelings, and behaviors related to classroom language learning arising from the uniqueness of the language learning process". Foreign Language Anxiety terdiri dari tiga dimensi yaitu communication apprehension, test anxiety and fear of negative evaluation.

Kecemasan sendiri memiliki peranan yang kecil ketika seseorang baru belajar bahasa. Pada saat ini, proses belajar lebih didorong oleh motivasi dan language aptitude memiliki peranan dominan dalam proses belajar. Namun dengan semakin banyaknya pengalaman yang tidak positif, maka semakin besar munculnya rasa cemas. Disebabkan lingkungan belajar di kelas dapat memunculkan kecemasan yang tinggi, maka merupakan prioritas guru untuk dapat menciptakan lingkungan kelas yang dapat menurunkan tingkat kecemasan siswa. Hal ini dapat dilakukan dengan mengajarkan strategi belajar yang tepat agar siswa dapat mengontrol kecemasan yang dirasakannya dan meningkatkan kinerja belajar.

Menurut Zeidner (1998) terdapat tiga aspek dalam kecemasan tes yaitu kognitif, afektif, dan perilaku. Ketiga aspek itu mempunyai gejala yang berbeda-beda.

\section{Aspek Kognitif}

Aspek kognitif dianggap sebagai reaksi kognitif yang negatif dari seseorang ketika dihadapkan pada situasi tes. Aspek kognitif terdiri atas dua kompunen yaitu worry dan self-preoccupation. Komponen worry dianggap sebagai gejala yang lebih menentukan 
kinerja seseorang dalam mengerjakan tes atau komponen paling berpengaruh yang dapat mengakibatkan penurunan kinerja dalam situasi evaluatif. Gejala ini merupakan gejala kognitif dari kecemasan, meliputi pemikiran bahwa situasi yang dinilai akan menyulitkan, memberikan perhatian pada implikasi dan konsekuensi kegagalan, berfikir mendapatkan hasil tes yang tidak memuaskan, ketidakpastian tentang kemampuan mengatasi konsekuensi tes, dan sangat terfokus dengan pikiran mengkritik diri.

Komponen self-preoccupation merupakan kecenderungan untuk menjadi sibuk dan terfokus pada diri sendiri ketika dihadapkan pada ancaman evaluasi. Gejala yang akan dimunculkan pada kecemasan ini meliputi dikuasai oleh ketakutan akan kegagalan, menyalahkan diri, mengkritik diri sendiri, penilaian yang melemahkan diri, kurang puas terhadap diri sendiri, keraguan terhadap kompetensi akademik diri, ragu terhadap kemampuan diri untuk mengatasi situasi yang menantang, pikiran merendahkan diri, memiliki keyakinan pesimis terhadap diri sendiri, keraguan diri dalam situasi ujian, melebih-lebihkan hasil perilaku negatif, perfeksionis, keyakinan bahwa diri tidak berdaya, dan merasa terasing dalam situasi penilaian.

\section{Aspek Afektif}

Zeidner (1998) menjelaskan bahwa aspek afektif terdiri atas gejala-gejala fisiologis dan emosi. Gejala fisiologis dalam kecemasan tes seperti gangguan lambung, rasa mual, berkeringat, tangan dingin dan lembab, buang air kecil, mulut kering, tangan atau tubuh gemetar, dan dada berdebar-debar. Stimulus atau situasi yang dipandang sebagai ancaman dapat membangkitkan state of anxiety, yaitu suatu keadaan emosional yang tidak menyenangkan yang terdiri atas perasaan tegang, kecemasan tentang masa depan yang tidak menyenangkan, gugup/nervous, khawatir, merasa tenang, merasa kesal, ketakutan terhadap sesuatu yang akan terjadi, santai, bingung, marah, dan sedih.

Individu dengan gejala emotionality akan sulit memusatkan perhatian pada tugas yang dihadapinya. Pikiran dipenuhi oleh hal-hal yang kurang relevan dengan sesuatu yang harus dikerjakannya seperti selama mengerjakan ujian timbul pikiran tidak percaya diri dan rendah diri, memikirkan hal-hal yang tidak ada hubungannya dengan tes, yang menjadi pengganggu dan hambatan dalam menyelesaikan tes dan perasaan-perasaan lain yang tidak menyenangkan.. 


\section{Aspek Perilaku}

Zeidner (1998) menjelaskan bahwa aspek perilaku dalam kecemasan tes merupakan perilaku yang timbul ketika siswa dihadapkan pada situasi tes/ujian. Gejala-gejala dari aspek perilaku biasanya timbul disertai dengan gejala fisiologis. Gejala dari perilaku kecemasan tes seperti menunda, menghindar, dan melarikan diri.

Perilaku penundaan pada siswa sebelum menghadapi ujian/tes yaitu penundaan pada akademiknya, perilaku diam merupakan sebuah penghindaran dari karakteristik siswa menghadapi kecemasan, dan siswa menjelang ujian/tes menunda-nunda untuk belajarnya. Perilaku menghindar dan melarikan diri hampir sama yaitu merupakan perangkat "melindungi diri sendiri" dalam mengurangi ketegangan dan stress sebelum ujian berlangsung, akan tetapi perilaku melarikan diri pada situasi tes adalah sebuah pikiran yang negatif. Dengan demikian perilaku melarikan diri tidak berlaku pada penelitian ini karena bagaimanapun siswa harus tetap mengikuti ujian yang akan terlaksana.

Dalam proses belajar bahasa asing ini terdapat berbagai faktor yang dapat menentukan sebaik apa seseorang pada akhirnya menguasai bahasa yang dipelajarinya. Terdapat enam faktor yang turut menentukan proses belajar bahasa Inggris dalam sebuah ruang kelas. Faktor-faktor ini juga yang dapat menentukan tingkat kecemasan yang dirasakan oleh seseorang yang sedang belajar bahasa Inggris. Keenam faktor tersebut adalah personal and interpersonal anxieties, learner belief about language learning, instructor belief about language learning, instructor-learner interaction, classroom, dan procedures language testing. Personal and interpersonal anxieties meliputi rasa persaingan dengan orang lain, cara berkomunikasi, kemampuan untuk menangkap, rasa malu, rasa takut di depan umum, adanya rasa takut untuk gagal, bagaimana seseorang meninai kemampuan bahasa Inggrisnya, dan kecemasan sosial. Kecemasan personal dan interpersonal ini menentukan bagaimana seseorang melihat dirinya sendiri dalam belajar bahasa Inggris serta bagaimana hubungannya dengan orang lain.

Faktor yang kedua adalah bagaimana pandangan orang tersebut terhadap proses belajar bahasa Inggris itu sendiri. Hal ini meliputi bagaimana orang tersebut melihat penting tidaknya belajar bahasa Inggris dan bagaimana dia memprioritaskannya, bagaimana dia mempersepsi kesalahan-kesalahan yang telah dia lakukan, serta bagaimana dia memandang kegiatan-kegiatan instrutural yang dilakuakan.

Faktor yang ketiga adalah instructor belief about language learning. Dalam hal ini instructor adalah guru yang mengajar. Bagaimana guru memandang proses belajar dan cara dia mengajar memberi pengaruh yang cukup besar terhadap proses belajar mengajar. 
Dalam hal ini pandangan guru terhadap muridnya meliputi peran dia sebagai guru dan bagaimana hubungan antara guru dan murid. Apabila hubungan antara guru dengan murid baik maka proses belajar-mengajar akan berjalan dengan lebih baik dan dengan hasil yang lebih baik

Faktor yang keempat adalah interaksi yang terjadi antara guru dan murid. Pada faktor ini yang menjadi titik fokusnya adalah bagaimana guru memperbaiki kesalahan yang dilakukan oleh oleh muridnya. Hal ini merupakan salah satu faktor yang penting karena cara guru memperbaiki kesalahan yang dilakukan oleh muridnya akan berpengaruh terhadap kecemasan yang dirasakan oleh murid tersebut.

Prosedur pelaksanaan tes bahasa asing juga merupakan salah satu faktor yang dapat menjadi sumber munculnya kecemasan. Prosedur pelaksanaan tes bahasa meliputi format pelaksanaan tes, item-item dalam tes, kesesuaian antara apa yang dipelajari dan dilatih dengan apa yang akan diuji. Faktor yang keenam adalah ruang kelas yang dimaksud dengan ruang kelas

Keenam faktor ini merupakana sumber-sumber kecemasan yang dapat dirasakan oleh seseorang ketika sedang belajar bahasa Inggris. Rasa cemas yang dimilki oleh seseorang kemudaian akan menentukan sebaik apa dia akan menguasai materi bahasa Inggris.

Dalam hal ini diperlukan sebuah strategi khusus yang dapat membantu mengurangi kecemasan tersebut. Salah satu strategi yang dapat mengurangi kecemasan adalah strategi relaksasi. Menurut Cormier (1995) "Relaxation training has been used with clients who have sleep disturbance, headache, hypertension, test anxiety, speech anxiety, asthma, excessive drinking, hyperactivity, and problems with anger control." Relaksasi telah digunakan untuk membantu konseli yang mengalami gangguan tidur, sakit kepala, hipertensi, kegelisahan sebelum mengikuti tes, kegelisahan saat berbicara di depan publik (berkomunikasi), asma, berlebihan dalam minum, hiperaktif, dan masalah yang berkaitan dengan pengendalian kemarahan.

Menurut Nursalim (2005) relaksasi otot bertujuan untuk mengurangi ketegangan dan kecemasan dengan cara melemaskan otot-otot badan. Dalam latihan relaksasi otot, individu diminta untuk menegangkan otot dengan ketegangan tertentu dan kemudian diminta mengendurkannya. Sebelum dikendurkan, penting dirasakan ketegangan tersebut sehingga individu dapat membedakan antara otot yang tegang dan yang lemas. Menurut Santoso (2001) "Latihan relaksasi pada dasarnya merupakan pemberian kesempatan pada tubuh untuk melakukan "pekerjaan rumah" 
sebelum pekerjaan itu diambil alih oleh pikiran rasional dan kognitif seseorang demi sebuah ego yang tidak mampu dikendalikan." Menurut berbagai pendapat diatas, dapat disimpulkan bahwa relaksasi adalah salah satu strategi dalam konseling yang merupakan suatu proses pembebasan mental dan fisik dari berbagai teknik sehingga dihasilkan keadaan yang lebih tenang. Dalam hal ini berhubungan dengan ketegangan dalam berkomunikasi interpersonal.

Subandi (2003) melaporkan beberapa keuntungan dari relaksasi, antara lain :

1. Relaksasi akan membuat individu lebih mampu menghindari reaksi yang berlebihan karena adanya stressor.

2. Masalah-masalah yang berhubungan dengan stressor seperti hipertensi, sakit kepala, insomnia dapat dikurangi atau diobati dengan relaksasi.

3. Mengurangi tingkat kecemasan.

4. Mengurangi kemungkinan gangguan yang berhubungan dengan stres, dan mengontrol anticipatory anxiety sebelum situasi yang menimbulkan kecemasan, seperti pada pertemuan penting, wawancara dan sebagainya.

5. Meningkatkan penampilan kerja, sosial, dan ketrampilan fisik.

6. Kelelahan, aktivitas mental dan atau latihan fisik yang tertunda dapat diatasi lebih cepat dengan menggunakan ketrampilan relaksasi.

7. Kesadaran diri tentang kesadaran fisiologis seseorang dapat meningkat sebagai hasil latihan relaksasi, sehingga memungkinkan individu untuk menggunakan ketrampilan relaksasi untuk timbulnya rangsangan fisiologis.

8. Relaksasi merupakan bantuan untuk menyembuhkan penyakit tertentu dan operasi.

9. Konsekuensi fisiologis yang penting dari relaksasi adalah bahwa tingkat harga diri dan keyakinan diri individu meningkat sebagai hasil kontrol yang meningkat terhadap reaksi stress.

10. Meningkatkan hubungan interpersonal. Orang yang rileks dalam situasi interpersonal yang sulit akan lebih berfikir rasional. 
Relaksasi akan menjadi efektif apabila relaksasi dilakukan sebagai metode kontrol diri. Beberapa bukti menyarankan bahwa peningkatan yang nyata akan terjadi jika individu merealisasikan relaksasi ketrampilan coping yang aktif untuk dipraktekkan dan diaplikasikan pada kehidupan sehari-sehari. Oleh karena itu penerapan relaksasi diharapkan adanya partisipasi aktif individu dalam memodifikasikan respon-respon terhadap peristiwa yang menekan.

Melihat betapa berpengaruhnya rasa cemas yang dimiliki oleh seseorang terhadap keberhasilan belajar seseorang maka diperlukan suatu cara yang dapat diterapkan oleh seseorang yang belajar bahasa Inggris untuk bias mengatasi rasa cemas yang dimilikinya. Oleh karena itu sangatlah penting agar seseorang yang belajar bahasa Inggris mengetahui cara terbaik baginya untuk belajar bahasa Inggris. Cara belajar ini disebut dengan language strategies, strategi belajar merupakan langkah-langkah, rencana, rutinitas yang digunakan oleh seseorang yang belajar agar dapat memfasititasi proses penerimaan, penyimpanan, retrieval dan penggunaan kembali suatu informasi. Ruang kelas sebagai tempat untuk proses pemecahan masalah, dimana seseorang akan menghadapi input dan tugastugas yang baru dan rumit, maka orang tersebut memerlukan suatu cara yang cepat dan mudah untuk dapat menyelesaikan tugas tersebut.

Dari penjelasan di atas maka dapat ditarik sebuah kerangka berfikir hubungan antara learning strategies dengan languange anxiety:

1. Setiap orang menggunakan learning strategies yang berbeda dalam belajar bahasa Inggris.

2. Siswa secara sadar memilih learning strategies yang digunakan sesuai dengan apa yang sedang dipelajarinya.

3. Kecemasan yang dirasakan oleh siswa dapat menghambat proses belajar bahasa Inggris.

4. Semakin banyak strategi belajar yang digunakan sesuai dengan tuntutan pembelajaran maka semakin rendah tingkat kecemasan yang dirasakan oleh siswa tersebut. 
Rasa cemas itu tumbuh karena pengalamanya yang berhubungan dengan peristiwa atau tindakan tertentu. Misalnya, ada siswa yang selalu cemas kalau menghadapi ulangan, ada yang cemas ketika menghadapi guru baru, ada yang cemas kalau pembelajaran dilaksanakan di luar kelas, dan sebagainya. Oleh sebab itu sangat penting bagi guru untuk melacak apakah kecemasan siswa itu berakar pada kecemasan global ataukah berakar pada kecemasan situasional.

Kecemasan bawaan karena sifatnya global dan sering ambigu batasanya tidak dapat digunakan untuk meramalkan keberhasilan belajar bahasa. Tetapi, akhirakhir ini, penelitian dalam hal kecemasan bahasa, menumpukan pada kecemasan situasional. Tiga komponen kecemasan belajar bahasa kedua telah diidentifikasi, yakni sebagai berikut.

1. Komunikasi dan pengertian, yang muncul dari ketidakmampuan pembelajar untuk mengekspirasikan secara layak pemikiran atau gagasan yang matang.

2. Takut akan evaluasi sosial yang negatif, muncul dari kebetulan untuk membuat kesan yang postif pada yang lain.

3. Tes kecemasan, atau pengertian akan evaluasi akademik.

Banyak penelitian menunjukkan bahwa kecemasan belajar bahasa kedua atau bahasa asing yang berdampak negative pada proses belajar bahasa. Kecemasan dapat dipisahkan menjadi kecemasan debilitatif dan fasilitatif. Dapat juga disebut sebagai kecemasan yang mengganggu dan membantu.

Aspek kecemasan yang diukur dari persentase tertinggi ke terendah meliputi perilaku, kognitif dan emosi. Berdasarkan hasil tersebut, maka upaya yang dapat dilakukan untuk membantu siswa mengatasi kecemasan adalah dengan coping skills. Menurut Lazarus (1996) coping adalah proses yang disertai dengan usaha dalam rangka mengubah domain kognitif atau perilaku secara konstan untuk mengatur dan mengendalikan tuntutan dan tekanan internal maupun eksternal yang diprediksi akan dapat membebani, melampaui kemampuan dan ketahanan individu yang bersangkutan.

Coping menentukan apakah seseorang sanggup bertahan menghadapi situasi yang tidak menyenangkan atau dianggap mengancam kemudian beradaptasi dengan kecemasan dan stress yang dirasakan atau tidak dirasakannya. Selain itu, coping tidak hanya selalu 
reaksi untuk menyelesaikan masalah, melainkan juga meliputi usaha menghindari, mentolerir, meminimalisir atau menerima kondisi yang penuh dengan tekanan. Coping merupakan suatu cara atau metode yang dilakukan oleh setiap individu untuk mengatasi dan mengendalikan situasi atau masalah yang dialami dan dipandang sebagai hambatan, tantangan yang bersifat menyakitkan, serta merupakan ancaman yang bersifat merugikan.

\section{Problem-Focused Coping (PFC)}

PFC cenderung digunakan pada saat individu menghadapi stressor yang dipersepsikan dapat dikendalikan. PFC melibatkan pengambilan tindakan langsung untuk mengubah situasi yang mengakibatkan stress, mencegah atau mengurangi dampaknya. Tujuan dari PFC adalah mengurangi tuntutan situasi atau meningkatkan kemampuan individu untuk mengatasi stressor.

Menurut Lazarus (1999) PFC terdiri atas tiga bentuk yaitu menghadapi (confrontational coping), dukungan sosial (social support), dan perencanaan mengatasi masalah (planful problem-solving). Pada Confrontational coping, individu tetap memegang teguh pendirian, menolak untuk berubah dan berusaha untuk mengubah keyakinan orang lain. Social support adalah meminta saran dan semangat dari teman dan keluarga. Planful problem-solving adalah melihat pilihan yang tersedia secara objektif, dan mempertimbangkan beberapa kemungkinan sebelum bertindak.

\section{Emotional-Focused Coping (EFC)}

EFC merupakan usaha untuk mengurangi ketegangan dan perasaan yang tidak menyenangkan yang timbul dari kesulitan atau masalah yang sedang dihadapi. EFC biasanya dipilih jika seseorang menilai sumber daya yang dimilikinya tidak cukup mampu untuk mengubah situasi yang dihadapinya sehingga dia hanya dapat menerima situasi tersebut. EFC tujuannya hanya mengurangi ketegangan dan perasaan yang tidak menyenangkan yang timbul dari masalah yang sedang dihadapi.

Menurut Lazarus et al. (1986) EFC terdiri atas lima bentuk yaitu self-control, distancing, reappraisal, accept responsibility, dan avoidance. Self-control adalah bertindak pasrah tidak memperlihatkan emosi. Distancing adalah menarik diri, memisahkan diri, dan mengambil jarak dari peristiwa yang penuh tekanan. Reappraisal adalah berusaha untuk melihat situasi dari perspektif berbeda, mencoba melihat sisi positifnya. Accept responsibility adalah memahami peran pribadi pada peristiwa yang 
dialami, mencoba belajar dari kesalahan. Avoidance adalah menolak untuk menerima perubahan dengan cara menghindari situasi.

Kecemasan dianggap sebagai salah satu faktor penghambat dalam belajar yang dapat mengganggu kinerja fungsi-fungsi kognitif seseorang, seperti dalam berkonsentrasi, mengingat, pembentukan konsep dan pemecahan masalah. Siswa yang mengalami kecemasan dalam komunikasi cenderung mengalami beberapa gangguan fisik maupun psikis. Gejala-gejala dalam gangguan fisik meliputi jantung berdebar-debar, gemetar, gugup, pernafasan tidak teratur, gangguan perut dan sebagainya. Sedangkan gangguan psikis meliputi perasaan takut, sulit konsentrasi, panik, tegang dan sebagainya.

Mengingat dampak negatifnya terhadap pencapaian prestasi belajar dan kesehatan fisik atau mental siswa, maka perlu ada upaya-upaya tertentu untuk mencegah dan mengurangi kecemasan siswa di sekolah:

1. Menciptakan suasana pembelajaran yang menyenangkan. Pembelajaran dapat menyenangkan apabila bertolak dari potensi, minat dan kebutuhan siswa. Oleh karena itu, strategi pembelajaran yang digunakan hendaknya berpusat pada siswa, yang memungkinkan siswa untuk dapat mengkspresikan diri dan dapat mengambil peran aktif dalam proses pembelajarannya.

2. Selama kegiatan pembelajaran berlangsung guru seharusnya dapat mengembangkan sense of humor dirinya maupun para siswanya. Kendati demikian, lelucon atau joke yang dilontarkan tetap harus berdasar pada etika dan tidak memojokkan siswa.

3. Melakukan kegiatan selingan melalui berbagai atraksi game atau ice break tertentu, terutama dilakukan pada saat suasana kelas sedang tidak kondusif. Dalam hal ini, keterampilan guru dalam mengembangkan dinamika kelompok tampaknya sangat diperlukan.

4. Sewaktu-waktu ajaklah siswa untuk melakukan kegiatan pembelajaran di luar kelas, sehingga dalam proses pembelajaran tidak selamanya siswa harus terkurung di dalam kelas. 
5. Memberikan materi dan tugas-tugas akademik dengan tingkat kesulitan yang moderat. Dalam arti, tidak terlalu mudah karena akan menyebabkan siswa menjadi cepat bosan dan kurang tertantang, tetapi tidak juga terlalu sulit yang dapat menyebabkan siswa frustrasi.

6. Menggunakan pendekatan humanistik dalam pengelolaan kelas, dimana siswa dapat mengembangkan pola hubungan yang akrab, ramah, toleran, penuh kecintaan dan penghargaan, baik dengan guru maupun dengan sesama siswa. Sedapat mungkin guru menghindari penggunaan reinforcement negatif (hukuman) jika terjadi tindakan indisipliner pada siswanya.

7. Mengembangkan sistem penilaian yang menyenangkan, dengan memberikan kesempatan kepada siswa untuk melakukan penilaian diri (self assessment) atas tugas dan pekerjaan yang telah dilakukannya. Pada saat berlangsungnya pengujian, ciptakan situasi yang tidak mencekam, namun dengan tetap menjaga ketertiban dan objektivitas. Berikanlah umpan balik yang positif selama dan sesudah melaksanakan suatu asesmen atau pengujian.

8. Di hadapan siswa, guru akan dipersepsi sebagai sosok pemegang otoritas yang dapat memberikan hukuman. Oleh karena itu, guru seharusnya berupaya untuk menanamkan kesan positif dalam diri siswa, dengan hadir sebagai sosok yang menyenangkan, ramah, cerdas, penuh empati dan dapat diteladani, bukan menjadi sumber ketakutan.

9. Pengembangan menajemen sekolah yang memungkinkan tersedianya sarana dan sarana pokok yang dibutuhkan untuk kepentingan pembelajaran siswa, seperti ketersediaan alat tulis, tempat duduk, ruangan kelas dan sebagainya. Di samping itu, ciptakanlah sekolah sebagai lingkungan yang nyaman dan terbebas dari berbagai gangguan, terapkan disiplin sekolah yang manusiawi serta hindari bentuk tindakan kekerasan fisik maupun psikis di sekolah, baik yang dilakukan oleh guru, teman maupun orangorang yang berada di luar sekolah. 
Melalui upaya-upaya di atas diharapkan para siswa dapat terhindar dari berbagai bentuk kecemasan dan mereka dapat tumbuh dan berkembang menjadi individu yang sehat secara fisik maupun psikis, yang pada gilirannya dapat menunjukkan prestasi belajar yang unggul.

\section{Prosedur}

Dalam penelitian ini menggunakan rancangan penelitian eksperimen dengan pretest-posttest group design. Subyek penelitian ini adalah siswa yang memiliki kecemasan komunikasi tinggi. Pemilihan subyek penelitian dengan purposive sampling. Siswa yang menjadi subyek penelitian sebanyak 10 orang mendapat perlakuan bimbingan kelompok dengan topik tugas. Instrument pengumpul data yang digunakan dalam penelitian ini adalah angket kecemasan komunikasi interpersonal.

Eksperimen dilakukan peneliti dalam enam kali pertemuan. Setiap pertemuan kurang lebih 45-60 menit. Pertemuan pertama berisi pembinaan hubungan dan rasional serta penentuan kesepakatan waktu berikutnya dan kegiatan berikutnya. Pada pertemuan berikutnya mulai dikenalkan gerakan-gerakan relaksasi, latihan relaksasi yang dilaksanakan 4 kali agar siswa menguasai gerakan relaksasi, sehingga latihan relaksasi tersebut bisa membantu siswa untuk mengurangi kecemasan komunikasi yang dialami mereka. Mereka juga diberi tugas rumah untuk melakukan relaksasi di rumah agar lebih terlatih dalam melakukan relaksasi.

Berdasarkan hasil post-test diperoleh bahwa terdapat perubahan kecemasan komunikasi interpersonal siswa, yaitu berkurangnya kecemasan komunikasi yang dialami siswa. Dapat disimpulkan bahwa terdapat perubahan terhadap kecemasan komunikasi interpersonal sebelum dan sesudah mendapat strategi relaksasi pada siswa.

\section{Kesimpulan}

Kecemasan (anxiety) adalah suatu perasaan tidak nyaman yang merupakan respons terhadap ketakutan atau kehilangan sesuatu yang bernilai. Kecemasan dengan intensitas yang wajar memiliki nilai positif sebagai motivasi, karena akan menyebabkan individu menjadi lebih waspada dan mendorong upaya yang lebih keras untuk mencapai apa yang 
diharapkan. Sementara dalam intensitas yang sangat kuat akan berdampak negatif karena mengganggu kondisi fisik dan psikis individu yang bersangkutan.

Terdapat perbedaan tingkat kecemasan komunikasi interpersonal yang dialami siswa kelas $\mathrm{X}$ antara sebelum dan sesudah diberikan perlakuan yaitu strategi relaksasi. Hal tersebut ditunjukkan dengan adanya peningkatan skor antara Pre-Test dan Post-Test. Dengan demikian dapat disimpulkan bahwa strategi relaksasi dapat digunakan untuk membantu mengurangi kecemasan komunikasi interpersonal siswa kelas.

Melihat besarnya pengaruh rasa cemas ketika sedang belajar bahasa Inggris, maka diperlukan suatu cara untuk mengatasi rasa cemas tersebut. Sebagai suatu proses belajar, maka dalam belajar bahasa Inggris terdapat beberapa strategi belajar yang dapat membantu seseorang belajar. Dengan menggunakan strategi belajar yang tepat maka proses belajar akan semakin afektif. Setiap orang memiliki strategi belajar yang bebeda yang digunakan dalam situasi belajar yang berbeda. Seseorang yang dapat menggunakan strategi belajar yang tepat pada saat yang tepat diharapkan dapat lebih cepat belajar bahasa Inggris. Yang pada akhirnya dapat menghilangkan rasa kecemasan dalam belajar bahasa Inggris.

\section{Daftar Rujukan}

Anwar, Syaifuddin. 2008. Penyusunan Skala Psikologi. Yogyakarta: Pustaka Pelajar. Atkinson, Rita. et.al. 2002. Pengantar Psikologi. Jakarta: Interaksara.

Brown, H. Douglas. 2001. Teaching by Principles: An Interactive Approach to Language Pedagogy. White Plains, NY: Pearson Education Company.

Cohen, A. D. 2000. Strategies in Learning and Using a Second Language. Foreign Language Teaching and Research Press.

Cormier,W.H \& Cormier,L.S. 1995. Interviewing Strategies For Helpers. Monterey California: Brooks/Cole Publishing.

Harmer, J. 1998. How to Teach English: An Introduction to the Practice of English Language Teaching. Essex: Addison Wesley Longman Ltd.

Lazarus, R. S. 1996. Pattern of Adjusment and Human Efectivenees. Kogakusha. McGraw Hill Book Compay.

Nursalim, Muhammad. 2005. Strategi Konseling. Surabaya : UNESA University Press. 
Santoso, AM Rukky. 2001. Mengembangkan Otak Kanan. Jakarta: Pustaka Gramedia.

Spielberger, Charles D. 1996. Anxiety and Behavior, New York : Academic Press .

Subandi dkk. 2003. Psikoterapi Pendekatan Konvensional dan Kontempor Yogyakarta : Pustaka Belajar.

Wolman, B.B.\& Sricker, G. 1994. Anxiety and Related Disorders a Handbooks. New York : John Wiley \& Sons, Inc.

Zeidner, M. 1998. Anxiety: The State of The Art. NewYork: Kluwer Academic Publishers. 